FLOOD OF JUNE 14-15, 1990, IN BELMONT, JEFFERSON, AND HARRISON COUNTIES, OHIO, WITH EMPHASIS ON PIPE AND WEGEE CREEK BASINS NEAR SHADYSIDE

By Harold L. Shindel

U.S. GEOLOGICAL SURVEY

Water-Resources Investigations Report 91-4147

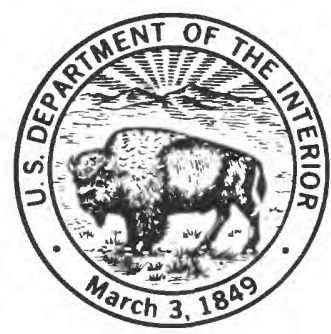

Columbus, Ohio 
U.S. DEPARTMENT OF THE INTERIOR

MANUEL LUJAN, JR., Secretary

U.S. GEOLOGICAL SURVEY

Dallas L. Peck, Director

For additional information write to:

District Chief Water Resources Division U.S. Geological Survey $975 \mathrm{~W}$. Third Avenue Columbus, OH 43212-3192
Copies of this report can be purchased from:

U.S. Geological survey Books and Open-File Reports Section

Box 25425

Denver Federal Center Denver, CO 80225 
Glossary of terms---

Abstract-1-

Introduction-

Purpose and scope--

Acknowledgments---

Weather associated with the flood----

Antecedent conditions---

Storms of June 14-15, 1990----------------------- 7

Flooding in the Pipe and Wegee Creek basins near Shadyside,

Ohio-- - - - - -

Procedures used in data collection----------- 7

Pipe Creek basin------_-

Wegee Creek basin---------

Flooding in Belmont, Jefferson, and Harrison Counties------- 17

Areal distribution of flooding--- 22

Historical perspective-- 22

Summary and conclusions--

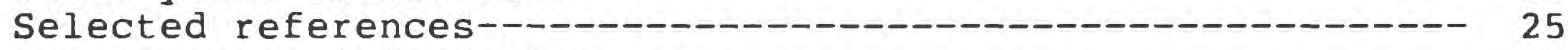

Supplemental information--

\section{ILLUSTRATIONS}

Figures 1-5. Maps showing:

1. Location of study area----------------- 2

2. May 1990 rainfall------------------- 5

3. Differences between normal May rainfall and May 1990 rainfall-- 6

4. Twenty-four-hour precipitation for the period ending 7:00 a.m., June 15, 1990-- 8

5. Pipe Creek study area--------------- 10

6. Flood and streambed profiles of Pipe Creek for flood of June 14, 1990--_-_-_--- 12

7. Map showing Wegee Creek study area-------- 16

8. Flood and streambed profiles of Wegee Creek for flood of June 14, 1990------ 18

9. Map showing continuous-record gaging stations, partial-record crest-stage gages, and miscellaneous sites, with area recurrence intervals of the June 14 , 1990, flood----------------------

10. Photoreproduction of front page of Bellaire Daily Leader for Monday, July 21, 1919--------------------- 
Table

Page

Table 1. Summary of hydrologic data for period of record and from the June 14-15, 1990, flood for selected sites in or near Belmont, Jefferson, and Harrison Counties-

CONVERSION FACTORS AND VERTICAL DATUM

\section{Multiply}

inch (in.)

foot (ft)

mile (mi)

square mile $\left(\mathrm{mi}^{2}\right)$

cubic foot per second $\left(\mathrm{ft}^{3} / \mathrm{s}\right.$ )

cubic foot per second

per ${ }_{3}$ square ${ }_{2}$ ile
By

25.4

0.3048

1.609

2.590

0.02832

0.01093

To obtain

millimeter

meter

$\mathrm{kilometer}$

square kilometer

cubic meter per

second

cubic meter per second per square $\mathrm{kilometer}$

Sea level: In this report, "sea level" refers to the National Geodetic Vertical Datum of 1929--a geodetic datum derived from a general adjustment of the first-order level nets of the United States and Canada, formerly called Sea Level Datum of 1929. 


\section{GLOSSARY OF TERMS}

The following are definitions of selected technical terms as they are used in this report; they are not necessarily the only valid definitions for these terms. Terms defined in the glossary are in bold print where first used in the main body of this report.

Continuous-record streamflow-gaging station.--A site at which gage height is measured repeatedly over time. Computation of a continuous-discharge record can be made from these measurements.

Discharge.--The volume of water that passes a given point within a given period of time. The unit of measurement used in this report is the cubic foot per second $\left(\mathrm{ft}^{3} / \mathrm{s}\right)$, which represents a volume of 1 cubic foot passing a given point during 1 second (equivalent to 7.5 gallons per second).

Peak discharge.--The maximum discharge passing a point within a given time interval.

Unit discharge.--In reference to surface-water flow, the number of cubic feet 3 per segond from each square mile of area drained $\left(\mathrm{ft}^{3} / \mathrm{s}\right) / \mathrm{mi}^{2}$; uniform runoff in space is assumed.

Drainage area.--That area measured in a horizontal plane that contributes surface runoff to a specified location on a stream.

Evapotranspiration.--A collective term that includes water discharged to the atmosphere as a result of evaporation from the soil and surface-water bodies and by plant transpiration.

Lift. - A mechanism needed to bring warm air from the surface to the upper atmosphere. Such mechanisms include frontal systems, low-pressure troughs, effects of terrain, and convection (caused by land-air temperature differences).

Miscellaneous site.--A site at which data are collected on an intermittent basis.

Normal.--As used by meteorologists, the average (or mean) conditions over a specific 30-year period ending in a year evenly divisible by 10 (updated every 10 years). The period applicable for this report is 1951 through 1980 . 
Partial-record crest-stage gage.--A site where only the peak, or highest, gage height is determined for the interval between site visits. Measurement of peak gage height allows the computation of a peak discharge during that time period.

Percolation.--The slow movement of water through openings within a porous earth material.

Recurrence interval (RI).--The average interval of time within which the magnitude of a given event, such as a flood, will be equaled or exceeded. A recurrence interval of 100 years for a peak discharge indicates that a flow of that magnitude would be equaled or exceeded on the average of once every 100 years. It is possible, however, that a peak discharge of that magnitude can be equaled or exceeded more than once within a much shorter time period.

Stage.--The height of the water surface in a stream above a predetermined point, usually on or near the channel floor. Used interchangeably with gage height.

Water-surface elevation.--The stage referenced to sea level datum.

Streambed elevation.--Streambed referenced to sea level datum.

Streamflow-gaging station.--A site on a stream where systematic observation of gage height is obtained by some sort of recording equipment for the purpose of computing streamflow. 
FLOOD OF JUNE 14-15, 1990, IN BELMONT, JEFFERSON, AND HARRISON COUNTIES, OHIO, WITH EMPHASIS ON PIPE AND WEGEE CREEK BASINS NEAR SHADYSIDE

By Harold L. Shindel

\section{ABSTRACT}

A series of violent thunderstorms caused severe floods and consequent damage in the central part of Ohio during June 14-15, 1990. The eastern part of the State, particularly Belmont, Harrison, and Jefferson Counties, sustained the most damage. In the Pipe and Wegee Creek basins near Shadyside, Belmont County, at least 24 people died and property damage exceeded \$10 million.

An indirect measurement of discharge on Pipe Creek, made near the mouth, indicates a peak discharge of $15,900 \mathrm{ft}^{3} / \mathrm{s}$ (cubic feet per second) for the drainage ${ }^{2}$ rea of $11.3 \mathrm{mi}^{2}$ (square miles) and a unit discharge of 1,330 ( $\mathrm{ft}^{3} / \mathrm{s}$ ) $/ \mathrm{mi}^{2}$ (cubic feet per second per square mile). The recurrence interval for this peak discharge is greater than 100 years. An indirect measurement of discharge on Wegee Creek, made 3 miles upstream from the mouth, indicates a peak discharge of $12,000 \mathrm{ft} / \mathrm{s}$ for the drainage area of $5.46 \mathrm{mi}^{2}$ and a unit discharge of $2,200\left(\mathrm{ft}^{3} / \mathrm{s}\right) / \mathrm{mi}^{2}$. The recurrence interval for this peak discharge also is greater than 100 years. Longitudinal water-surface profiles showed depths ranging from $7 \mathrm{ft}$ to $22 \mathrm{ft}$.

The severity of flooding was highly variable. For example, the recurrence interval of the peak discharge at one U.S. Geological Survey streamflow-gaging station was only 2 years, whereas the recurrence interval for the peak discharge was greater than 100 years at another gaging station about 22 miles away.

\section{INTRODUCTION}

At around 9:00 p.m., June 14, 1990, flood waves swept down Pipe and Wegee Creeks, two small creeks in eastern Ohio that are tributary to the Ohio River (fig. 1). According to witnesses, the flood waves, caused by an intense short-duration storm, were like walls of water as much as $20 \mathrm{ft}$ high (Jacobs, 1990). 


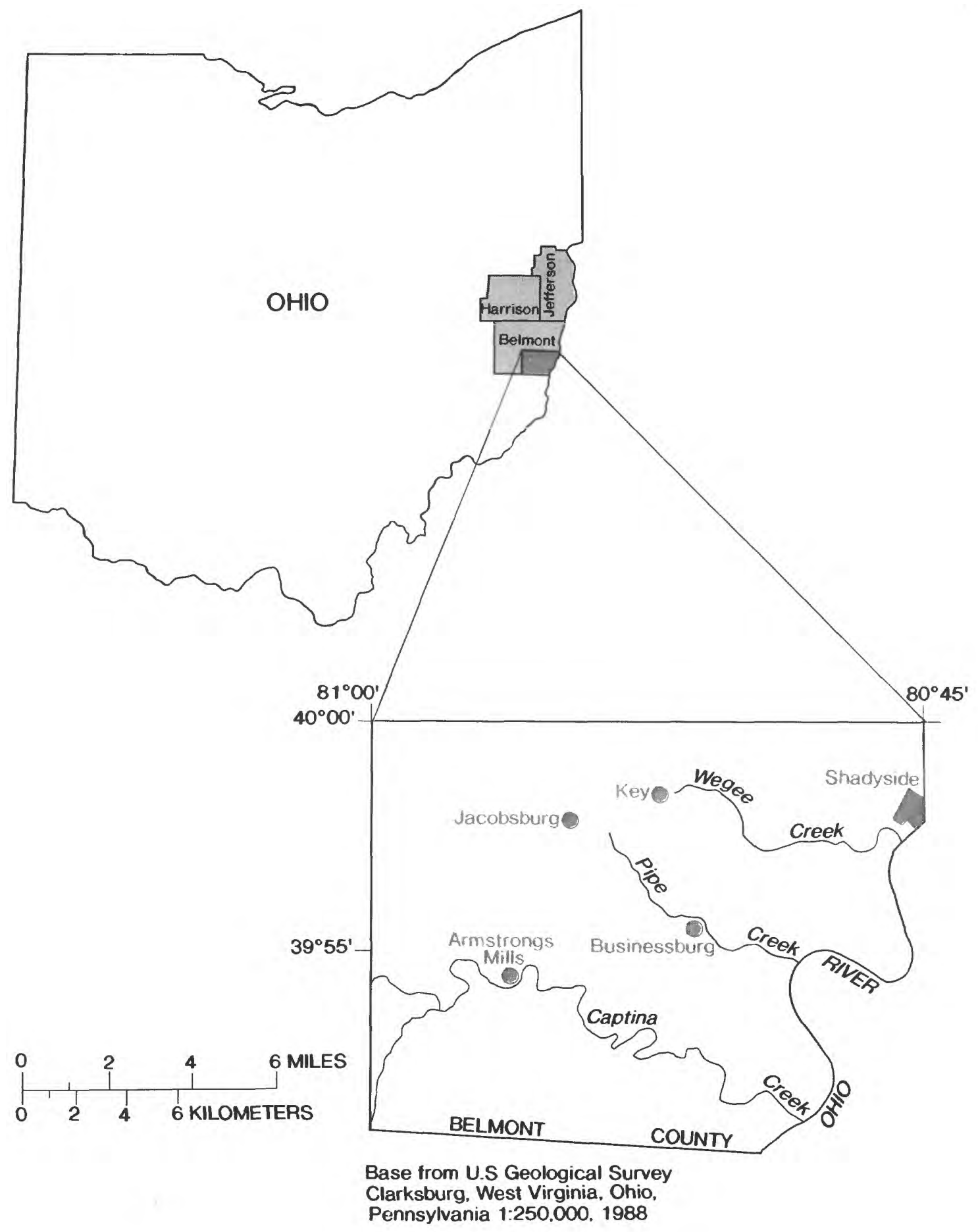

Figure 1.--Location of study area. 
At least 24 people lost their lives in these two basins. Twelve people were killed on Wegee Creek; twelve were killed on Pipe creek. Two other deaths resulted from flooding on another nearby creek. A number of factors led to the high fatality rate, but the most significant were the time that the flooding took place (9:00-9:30 p.m.) and the suddenness of the flooding.

Damages were reported in at least 18 counties in central Ohio. The damage estimates listed below for Belmont, Harrison, and Jefferson Counties (G. Keller, State of Ohio Adjutant General's department, written commun., 1990) are based solely on the approved county Damage Survey Reports.

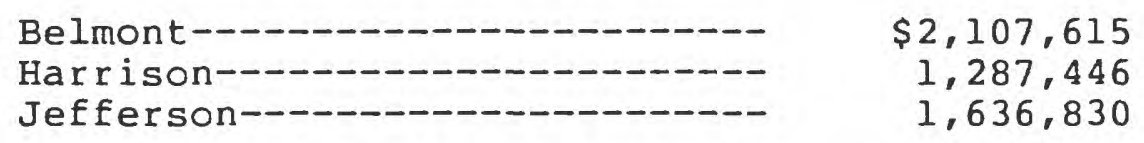

The U.S. Army Corps of Engineers, Pittsburgh District, reported a higher damage total, $\$ 10.1 \mathrm{million}$, for the Pipe and Wegee Creek basins, with the damage divided about evenly between the two basins (Michael Irr, U.S. Army Corps of Engineers, oral commun., 1991). The damage estimate included 145 residences damaged and 58 destroyed, infrastructure repairs, relief efforts, and reconstruction expenses. The Corps of Engineers assessment included many items not accounted for in the county Damage Survey Reports.

\section{Purpose and Scope}

This report describes the weather and flooding of June 14-15, 1990, in Belmont, Harrison, and Jefferson Counties, with emphasis on the Pipe and Wegee Creek basins. Specific hydrologic data are presented for the three-county area on the basis of existing U.S. Geological Survey (USGS) streamflow-gaging stations in the area. Peak water-surface elevations were determined at points along Pipe and Wegee Creeks to develop flood profiles. Indirect determinations of discharge were made at one location on each of these ungaged streams. The history of flooding in the area is discussed.

\section{Acknowledgments}

Much of the data collection and interpretation were based on the combined efforts of many individuals in the private and public sectors. Much of the information in the supplemental Information section was provided by Margaret Kirkland, a local resident and retired educator currently working on a history of Belmont county.

1 Terms defined in the glossary are in bold print where first used in the main body of this report. 
Weather-condition reports were provided by the Ohio Department of Natural Resources (ODNR) and the National Weather Service (NWS). Damage assessment in the three-county area was furnished by the State Disaster Relief Agency, and the assessment of damages in the Pipe and Wegee basins was provided by the U.S. Army Corps of Engineers, Pittsburgh District.

\section{WEATHER ASSOCIATED WITH THE FLOOD}

The storms of June 14-15, 1990, followed an unusually wet spring in eastern ohio. The severity of the flooding was partly due to the inability of the saturated soils to absorb storm rainfall.

\section{Antecedent Conditions}

Rainfall was above normal throughout the State for the months of January through April 1990. The average precipitation for the state for that period was $18.68 \mathrm{in.,} 3.04 \mathrm{in}$. above normal. Regional averages ranged from 5.81 in. above normal for the Southwest region to $1.65 \mathrm{in}$. above normal for the North Central region (Cashell, 1990).

Average rainfall for May 1990 was above normal. The average rainfall for the state in May 1990 was 7.06 in., 3.31 in. above normal. May 1990 was ranked as the second wettest May on record in 108 years. Regional averages ranged from 5.92 in. above normal for the Southwest region to $1.37 \mathrm{in}$. above normal for the North Central region. During May 3-4, more than 2 in. of rain fell at many locations from the southwestern to north-central parts of the state. From 2 to 3 in. of rain fell in the southern two-thirds of Ohio during May 13-17. Many locations in southeastern Orio received another 2 in. of rain during May 25-26. On May 28, the southern half of the State received an additional 2 to 4 in. of rain.

Rainfall during May 1990 is shown in figure 2. The average precipitation in each of the regions and the May 1990 departure expressed as a percentage of normal are shown in figure 3 .

The amount of water in the soils of eastern ohio during this period is indicated by the Palmer Drought Severity Index (National Weather Service, 1990), which depicts prolonged abnormal dryness or wetness. This index usually responds slowly (changes little from week to week) and reflects long-term changes in moisture, runoff, recharge, deep percolation, and evapotranspiration rates. The Palmer Index at the end of May for the Southeast region of the State (where Pipe and Wegee Creeks are located) was +2.7 (Cashell, 1990), which indicates an 


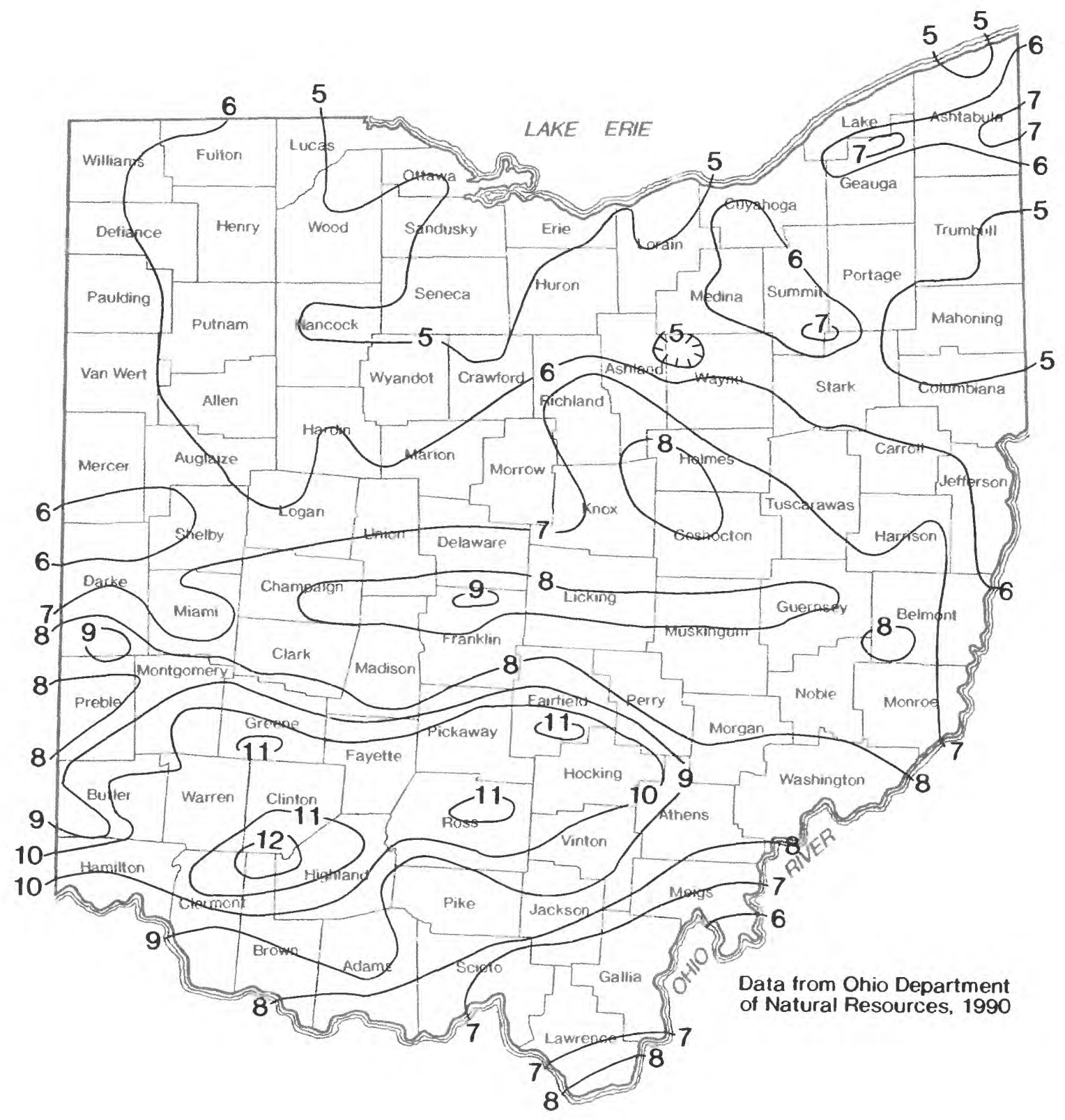

EXPLANATION

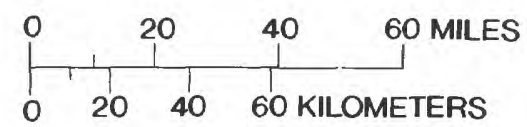
-6- LINE OF EQUAL PRECIPITATION--Contour interval 1 inch

Figure 2.--May 1990 rainfall. 

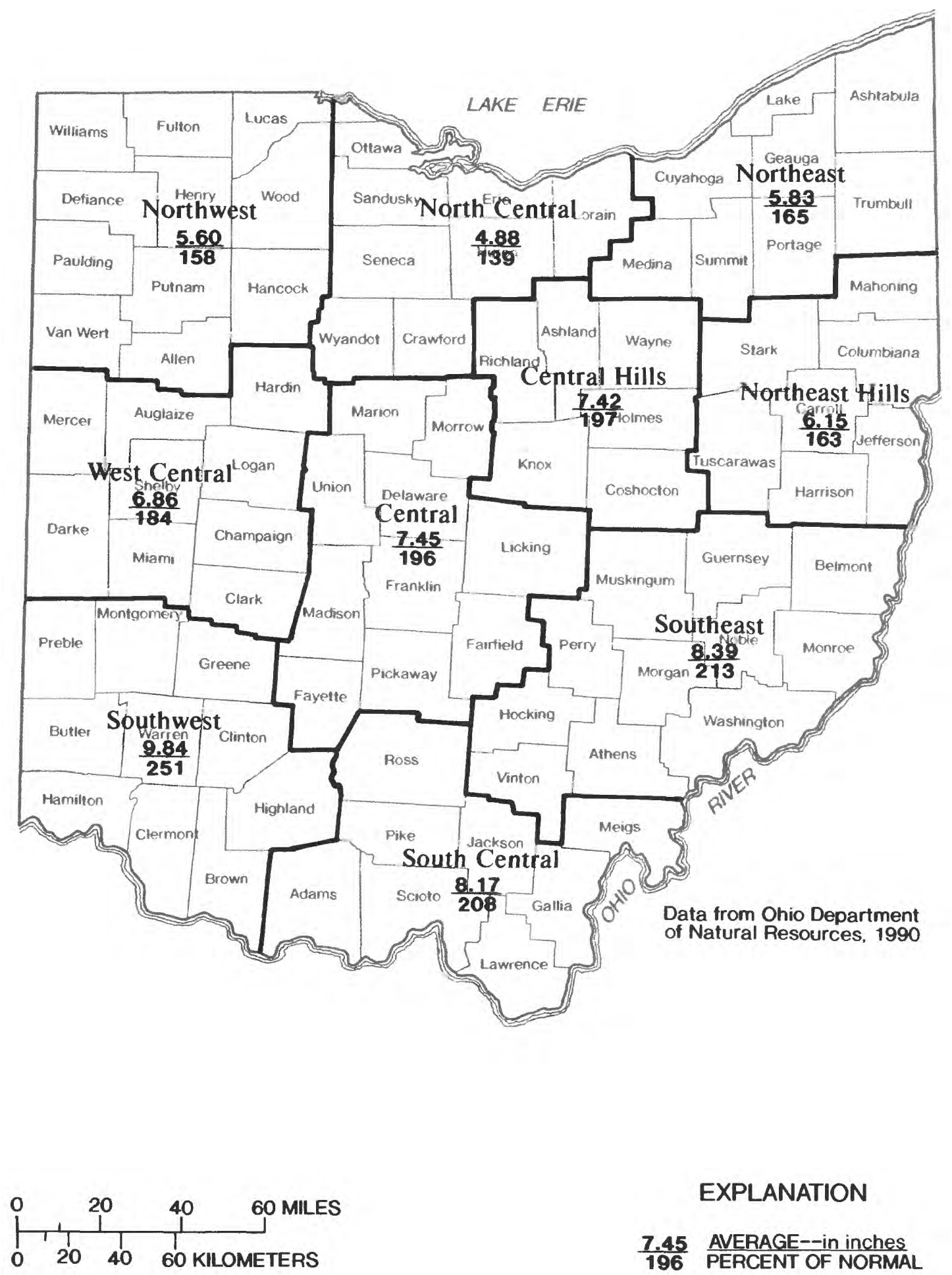

EXPLANATION

$\frac{7.45}{196}$ AVERAGE--in inches

Figure 3.--Differences between normal May rainfall and May 1990 rainfall. 
"Unusual Moist Spel1." By June 9, 1990, the Palmer Index for the Southeast region was about 3.2 (National Weather Service, 1990), which indicates a "Very Moist Spell." This relatively rapid change indicates the unusual spring wetness.

\section{Storms of June 14-15, 1990}

On June 14, 1990, a series of slow-moving thunderstorms moved eastward across the midsection of Ohio. Isolated storm cells delivered from 1 in. to more than 3 in. of rain at many locations. A total of 5 in. of rain fell on the BelmontHarrison-Jefferson County area over a 24-hour period.

In an extensive analysis of this storm (National Weather Service, 1991), the NWS found that three key conditions conducive to thunderstorms existed: moisture, instability, and a source of lift. A weak upper-air disturbance crossed Ohio from west to east during the day. By evening, a low-pressure system had developed over southeastern Ohio, which had the effect of drawing moisture-laden air into the atmosphere over the three-county area. Instability of the various air masses increased during the day, especially over east-central and southern Ohio. The amount of moisture in the air increased as the upper-air temperatures rose. At 8:00 p.m., the amount of water in the air was 160 to 190 percent of normal.

One of the end results of all this activity was the generation of a high-intensity thunderstorm over the three-county area. According to the National weather Service (1991), this storm delivered 3 to 4 in. of rain between $8: 30$ and 9:45 p.m. The greatest rainfall occurred in a band from southeastern Harrison County to northeastern Belmont County.

The 24-hour precipitation across the southern two-thirds of Ohio is shown in figure 4. The area of greatest rainfall was centered on Belmont, Harrison, and Jefferson Counties.

FLOODING IN THE PIPE AND WEGEE CREEK BASINS NEAR SHADYSIDE, OHIO

Flood marks and the high-water profiles are presented in the Pipe Creek basin and Wegee Creek basin sections of the report.

\section{Procedures Used in Data Collection}

High-water marks along both banks of Pipe and Wegee Creeks were flagged on June 16, 17, 21, and 22, 1990. These marks and streambed elevations were subsequently referenced to sea level by field surveys. 

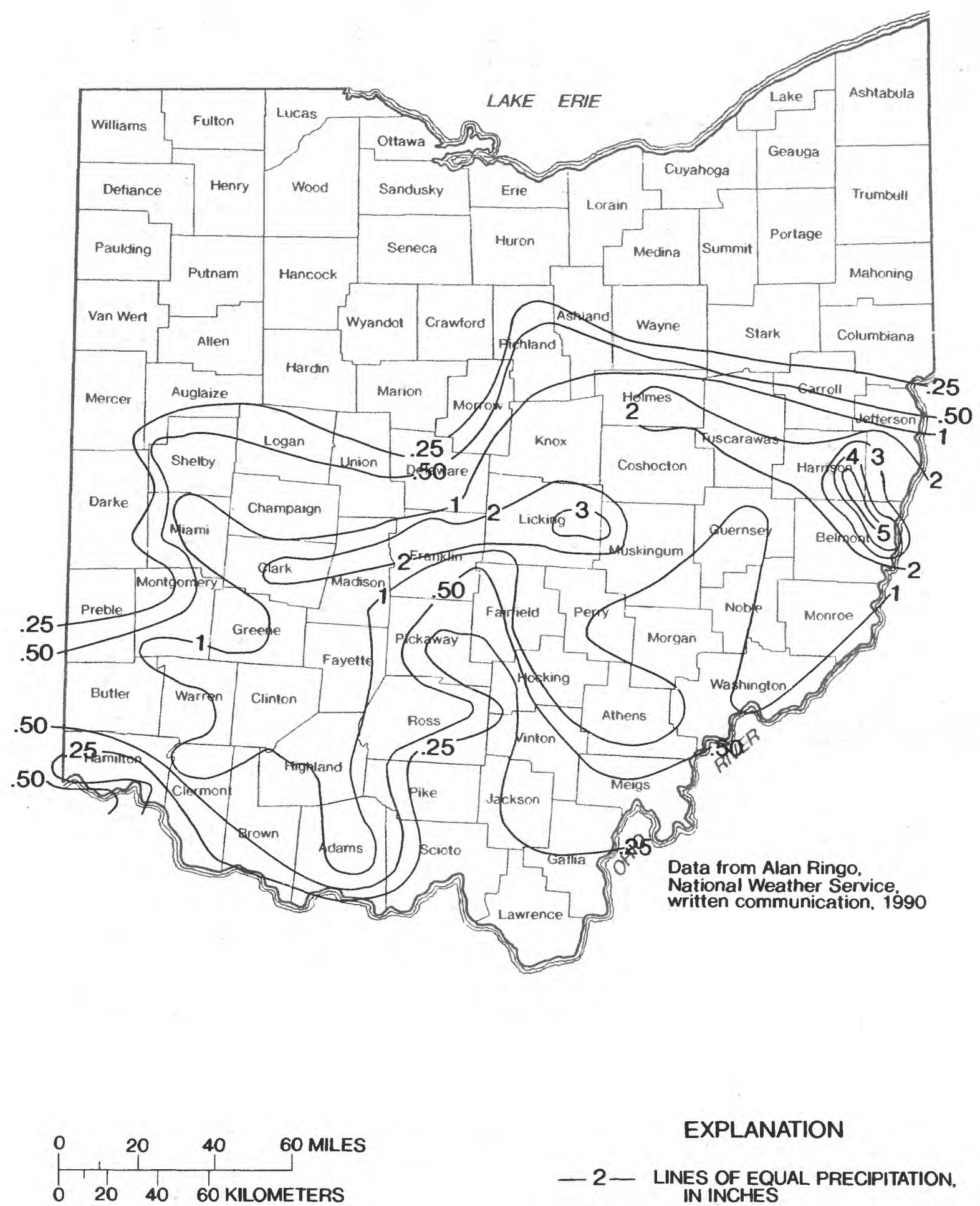

EXPLANATION

- 2- LINES OF EQUAL PRECIPITATION. IN INCHES

Figure 4.--Twenty-four-hour precipitation for the period ending 7:00 a.m., June 15, 1990. 
All surveyed points are plotted in figures 6 and 8 . Some parts of the profiles were obtained by averaging several points. Because of a number of factors, including high velocities, steep channel slopes, turbulent flow, and debris, judgment was used in determining the water-surface profile. The lines connecting the points do not necessarily represent the actual water-surface or streambed profile but are presented as a visual aid.

Indirect measurements were necessary to estimate the peak discharges because the suddenness and short duration of the flood made direct measurement impossible. In indirect measurements, information recovered after a flood is used to estimate the peak discharge of the flood. After preliminary reconnaissance of the Pipe Creek and Wegee Creek basins, a suitable reach was found on each stream to make an indirect measurement of the peak discharge by the slope-area method.

The slope-area method is one of the most commonly used methods for indirect determinations of discharge. In the slopearea method, discharge is computed on the basis of the Manning equation. This gradually varied flow equation is always used:

$$
Q=(1.486 / \mathrm{n}) \mathrm{AR}^{2 / 3} \mathrm{~S}^{1 / 2} \text {, }
$$

where

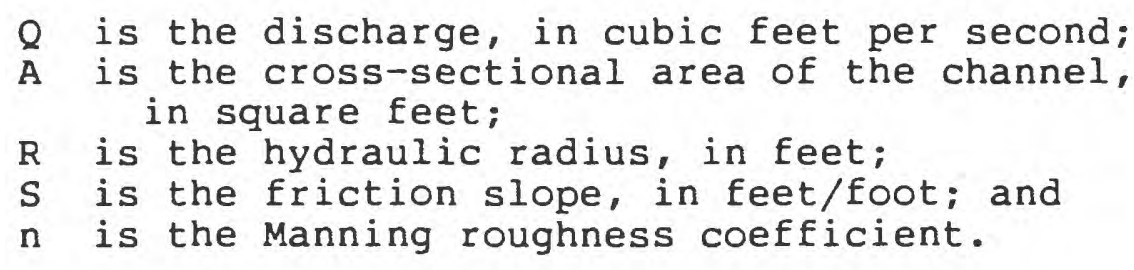

Field surveys are necessary to define the water-surface profile through the reach and to determine the cross-section characteristics. Among these characteristics is the roughness coefficient, which is based on the physical characteristics of the stream and the flood plain.

Peak discharges for Pipe and Wegee Creeks were determined by use of the USGS computer algorithm for slope-area measurements (O.G. Lara and Jacob Davidian, U.S. Geological Survey, written commun., 1970).

\section{Pipe Creek Basin}

The headwaters of Pipe Creek are $1.5 \mathrm{mi}$ west of Key, Ohio, although the headwaters of one of the tributaries to Pipe Creek are just south of Key (figs. I and 5). Pipe Creek flows through an area of steep slopes. For most of the length of the basin, the slopes of adjacent hills are approximately 30 degrees. 


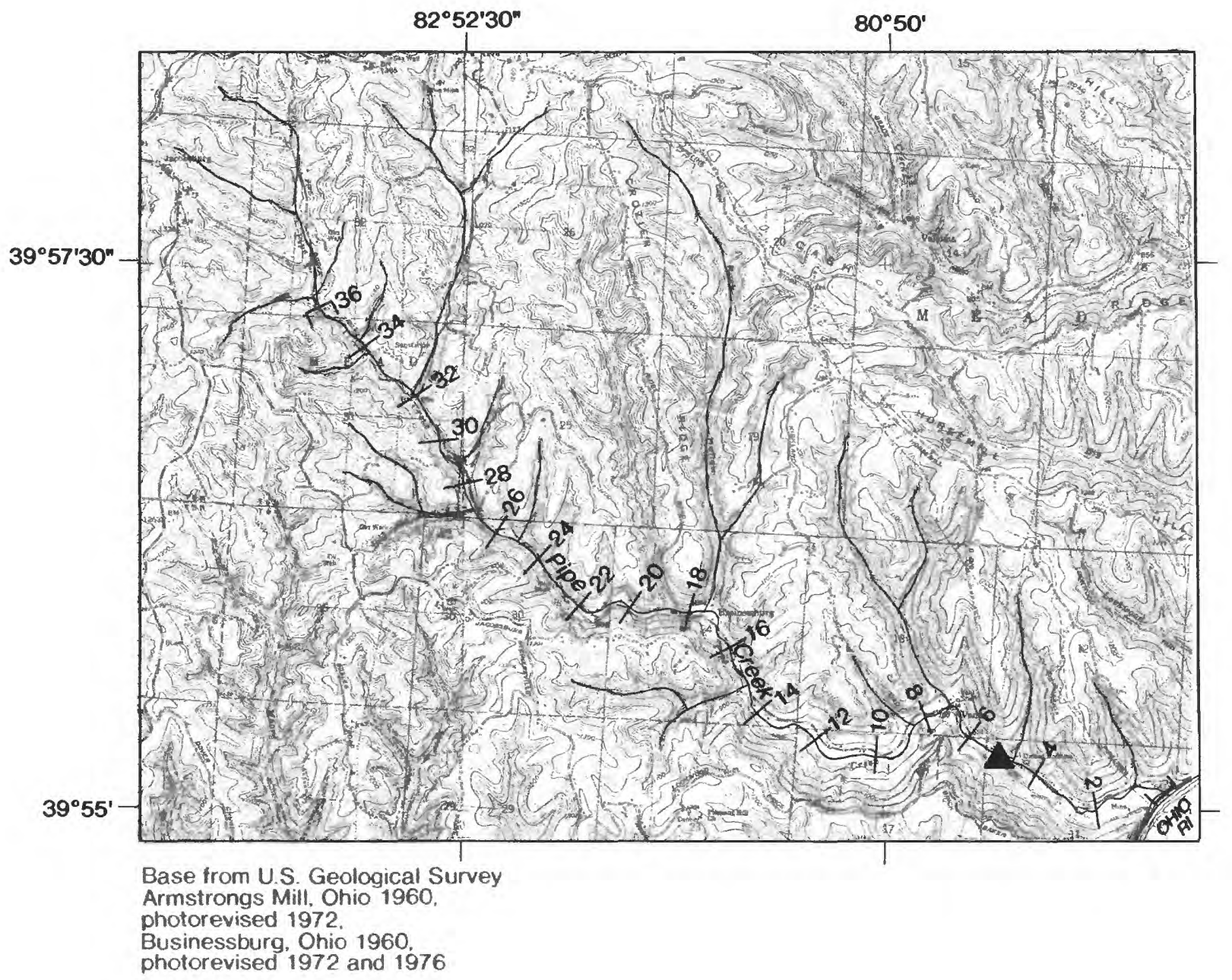

EXPLANATION

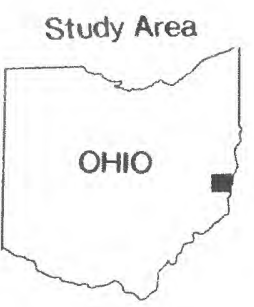

[ ] PROFILE SECTION

- INDIRECT-MEASUREMENT SITE

- 10 DISTANCE FROM MOUTH-in thousands of feet

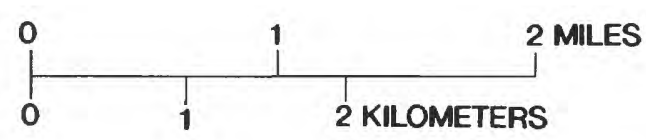

Figure 5.--Pipe Creek study area. 
The basin elevation ranges from 1,350 ft above sea level at the headwaters to $625 \mathrm{ft}$ above sea level at the mouth. The drainage area of Pipe Creek is $12.5 \mathrm{mi}^{2}$ at the mouth.

The flood profile reach extends from the mouth to a point about $6.8 \mathrm{mi}$ upstream. The width of the valley floor averages 200 to $250 \mathrm{ft}$ for most of the reach but exceeds $500 \mathrm{ft}$ in places. The difference in streambed elevation from near the mouth (618 ft) to the head of the study reach $(1,063 \mathrm{ft})$ is $445 \mathrm{ft}$. The average channel slope is $0.0124 \mathrm{ft} / \mathrm{ft}$ or $65.3 \mathrm{ft} / \mathrm{mi}$.

The peak discharge on Pipe creek at the indirect measurement site, 4,600 ft upstream from the mouth (drainage area, $11.3 \mathrm{mi}^{2}$ ), was $15,000 \mathrm{ft} / \mathrm{s}$. This discharge corresponds to a unit discharge of $1,330\left(\mathrm{ft}^{3} / \mathrm{s}\right) / \mathrm{mi}^{2}$. A recurrence interval could not be computed because historical data are not available. A regional regression equation for flood-frequency (Koltun and Roberts, 1990) was used to estimate discharge for a 100-year flood at this sitg. On the basis of the regional equątion estimate of $3,440 \mathrm{ft}^{3} / \mathrm{s}$, the peak discharge of $15,000 \mathrm{ft}^{3} / \mathrm{s}$ is well in excess of a 100-year flood. The water-surface elevation at the downstream end of the indirect-measurement reach $(4,600 \mathrm{ft}$ upstream from the mouth) was $665 \mathrm{ft}$ above sea level, which corresponds to a stream depth of $12 \mathrm{ft}$.

The flood profile shown in figure 6 essentially paralleled the streambed profile, although, in some cases, the floodwater surface was unaffected by small waterfalls and irregularities in the channel. The lack of effect of channel features can be seen in the profile at the waterfalls 12,000 and $17,000 \mathrm{ft}$ upstream from the mouth and at a series of smaller waterfalls that are between 25,000 to $33,500 \mathrm{ft}$ upstream from the mouth. Large waterfalls, such as the one $6,500 \mathrm{ft}$ upstream from the mouth, affect the water surface. Stream depths in the reach averaged $14 \mathrm{ft}$ and ranged from $7 \mathrm{ft}$ near the headwaters to $17 \mathrm{ft}$ near the mouth.

\section{Wegee Creek Basin}

The headwaters of Wegee Creek rise near the village of Key, Ohio, which is $6 \mathrm{mi}$ west of Shadyside, Ohio (figs. 1 and 7 ). The stream is in an area of steep slopes. For most of the length of the basin, the slopes of adjacent hills are approximately 30 degrees. The land-surface elevation ranges from about $1,300 \mathrm{ft}$ above sea level at the headwaters to about $630 \mathrm{ft}$ at its mouth on the Ohio River (at River Mile 98.7). The drainage area of Wegee Creek is $12.8 \mathrm{mi}^{2}$ at the mouth. 


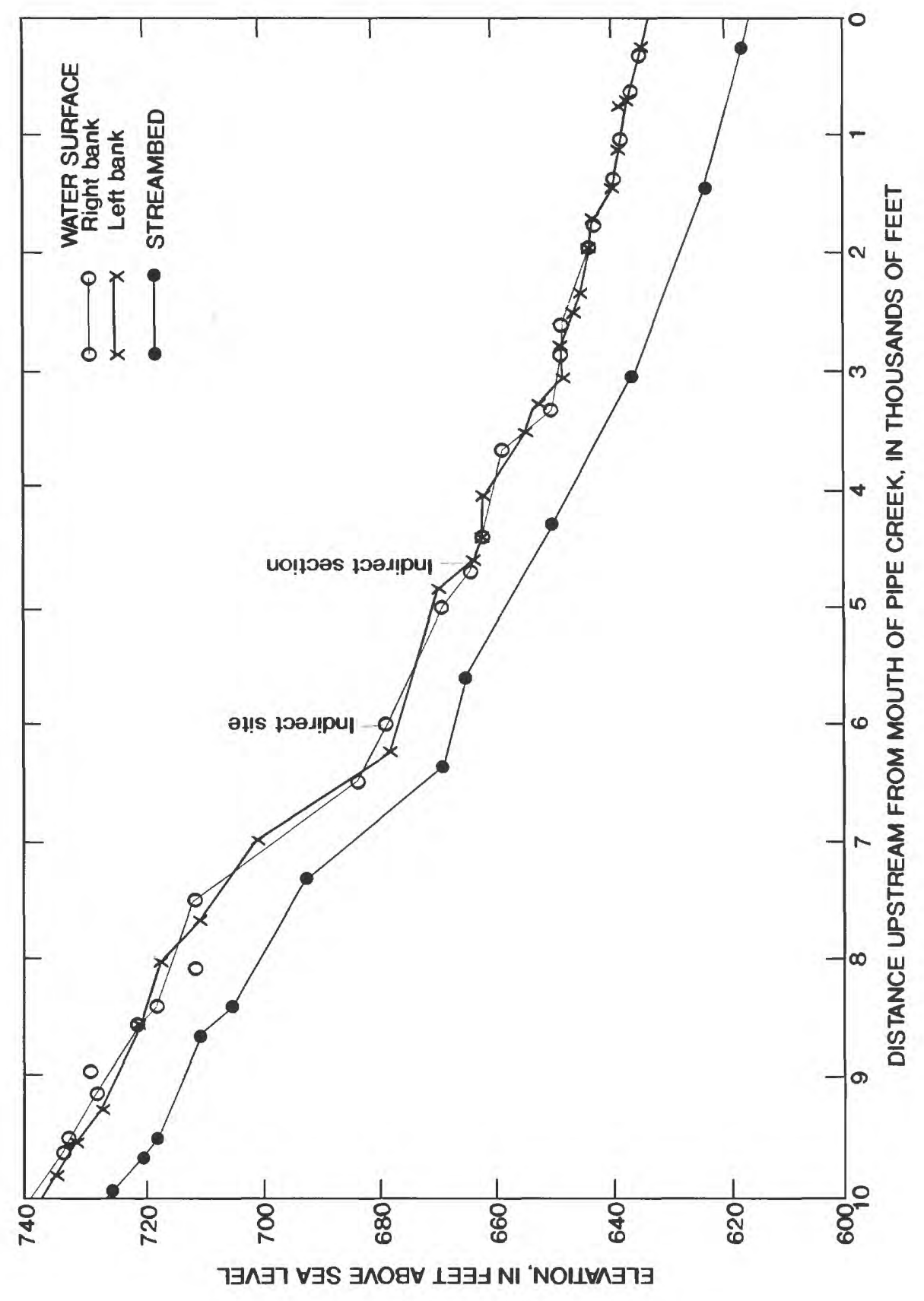

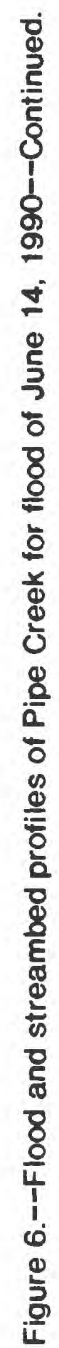




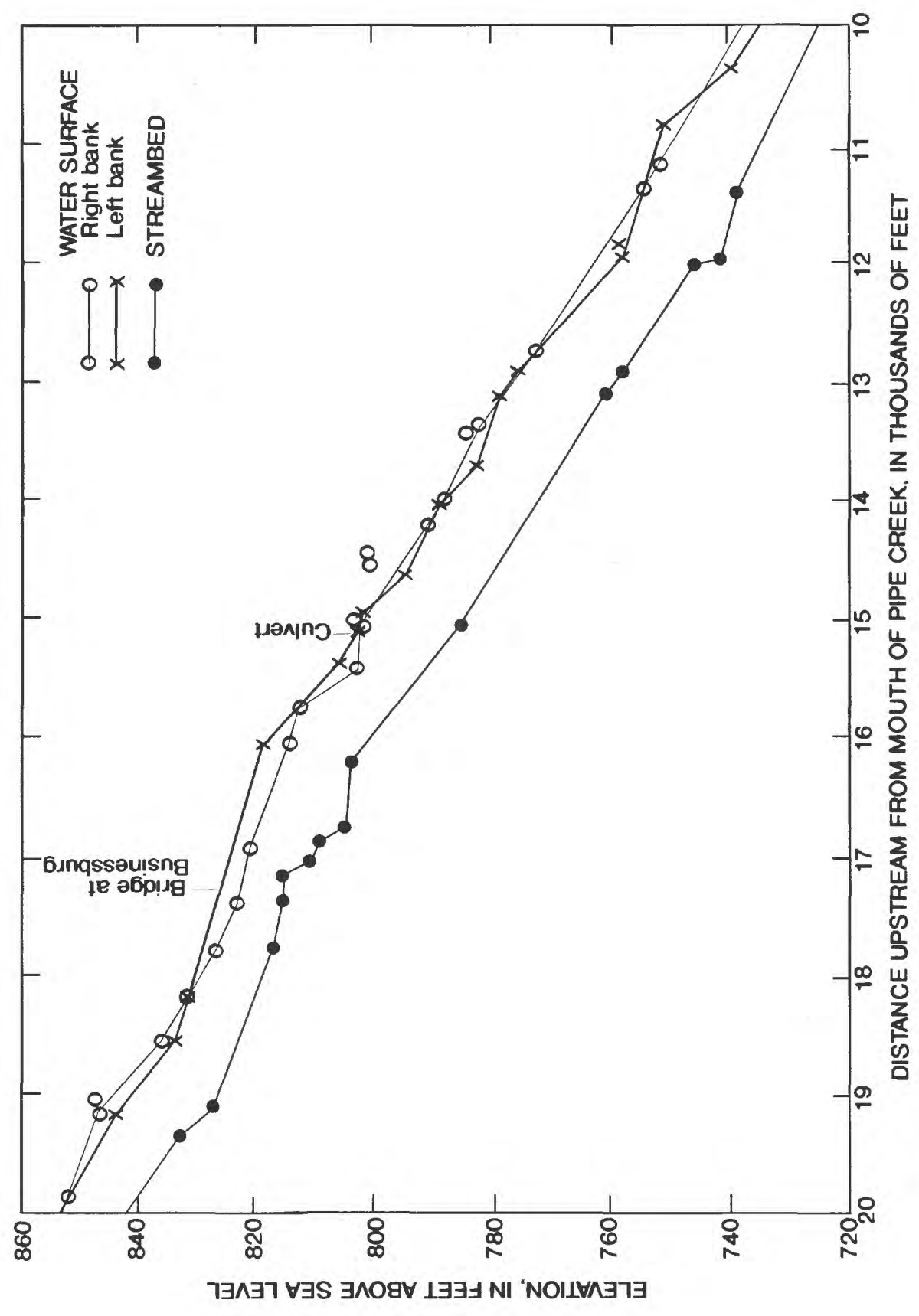

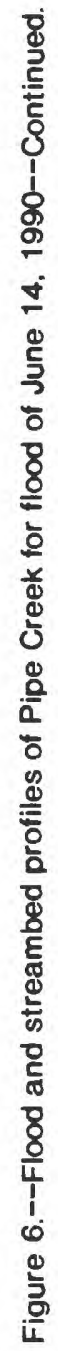




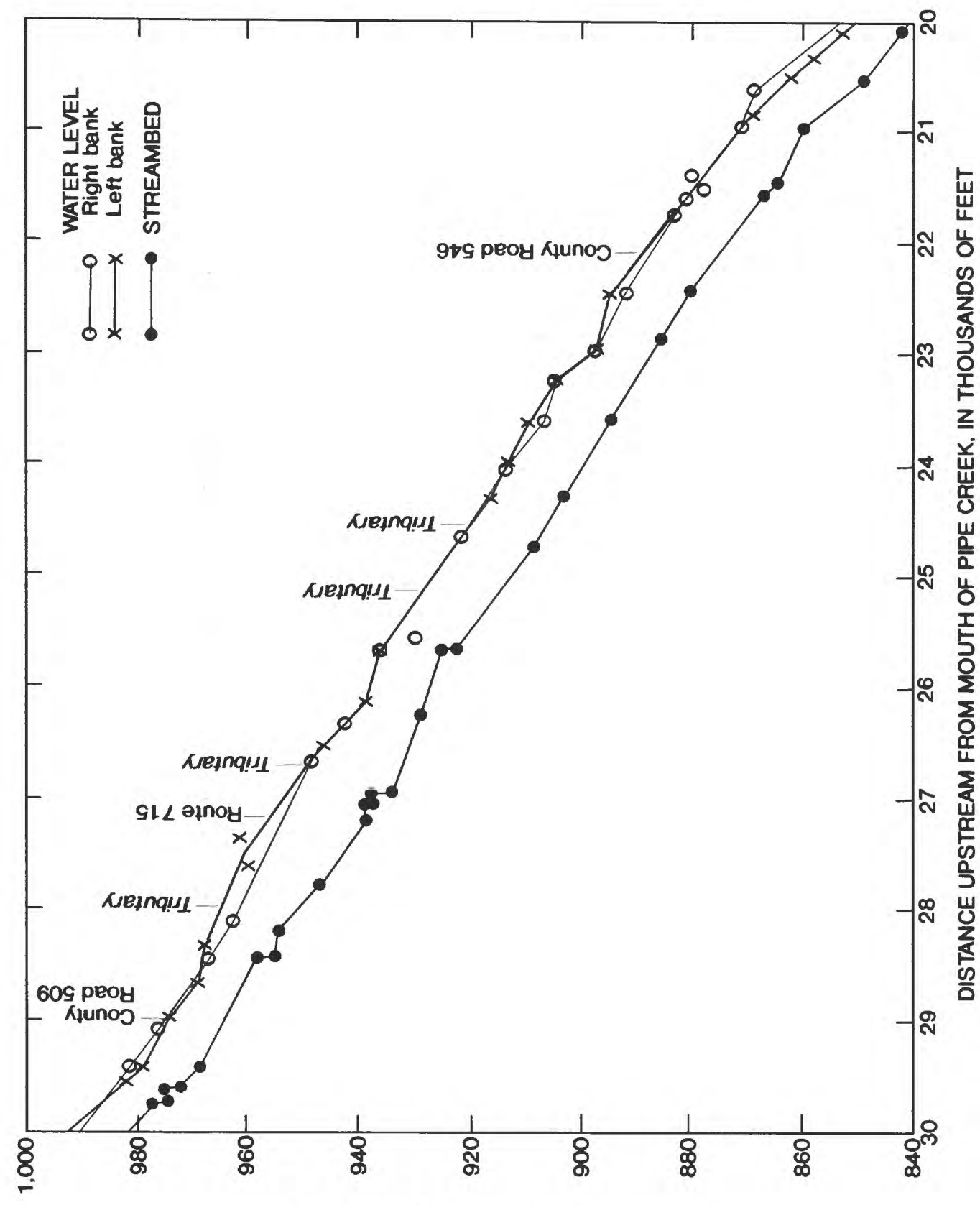

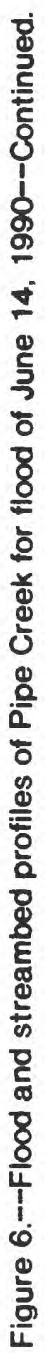

า 


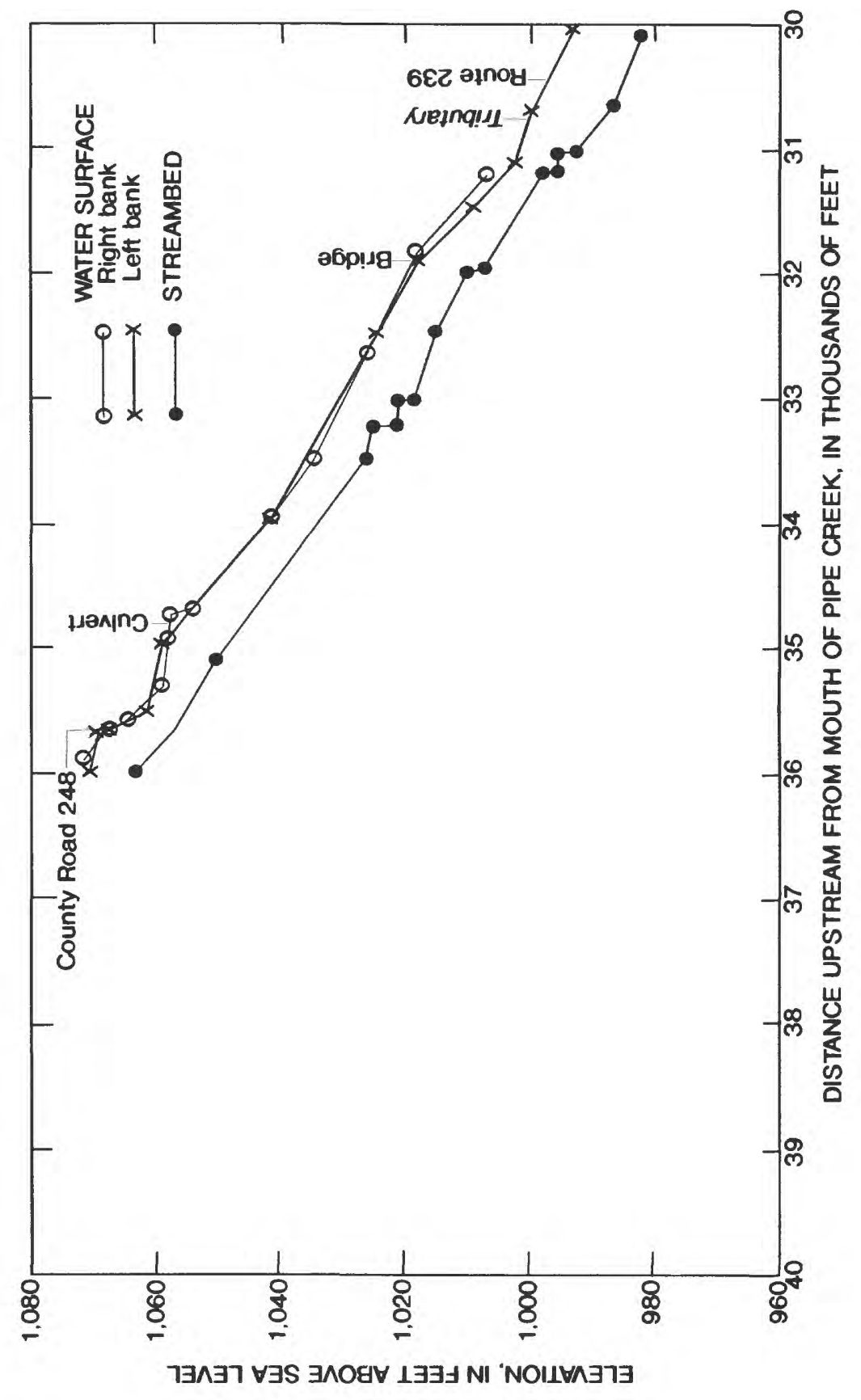

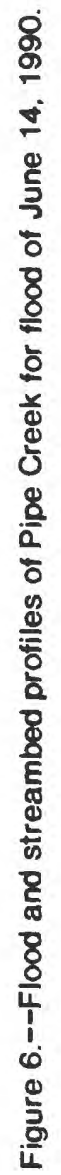



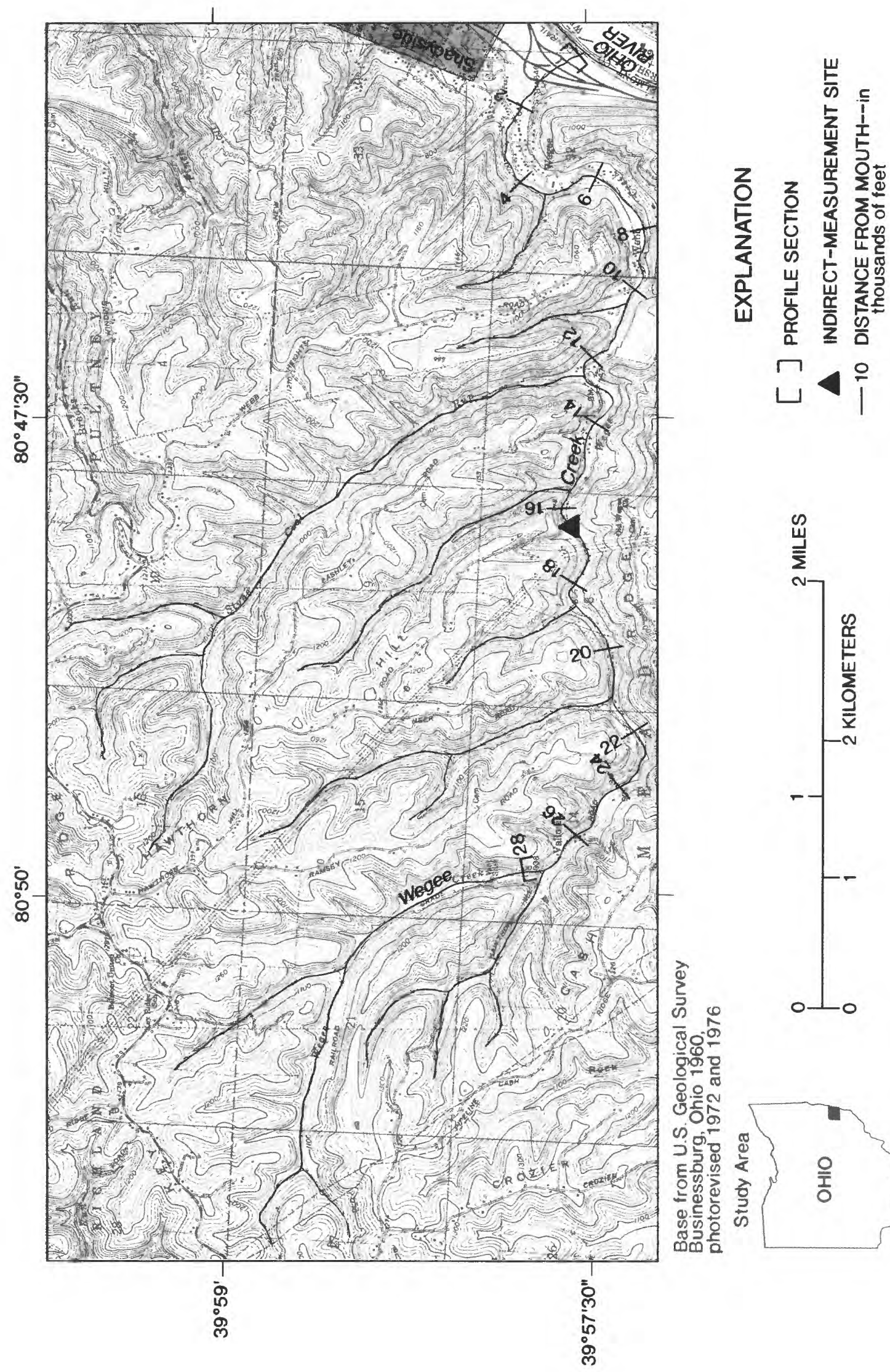

ฮึ่ 
The flood-profile reach extends from the mouth to a point about $5.4 \mathrm{mi}$ upstream. The width of the valley floor averages 200 to $250 \mathrm{ft}$ for most of the length of the reach, but widths are as great as $700 \mathrm{ft}$ in places. The valley widens considerably near the mouth. The difference in streambed elevation from the mouth $(610 \mathrm{ft})$ to the head of the study reach $(940 \mathrm{ft})$ is $330 \mathrm{ft}$. The average channel slope in the study reach is $0.0116 \mathrm{ft} / \mathrm{ft}$, or $61.1 \mathrm{ft} / \mathrm{mi}$.

The peak discharge on Wegee Creek at the indirect measurement sife, $17,000 \mathrm{ft}$ upstream from the mouth (drainage area, $5.46 \mathrm{mi}^{2}$ ), was approximately $12,000 \mathrm{ft}^{3} / \mathrm{s}$. This discharge corresponds to a unit discharge of $2,200\left(\mathrm{ft}^{3} / \mathrm{s}\right) / \mathrm{mi}^{2}$. A recurrence interval could not be computed because historical data are not available. On the basis of the regional equation estimate of $1,950 \mathrm{ft}^{3} / \mathrm{s}$, the peak discharge of $12,000 \mathrm{ft}^{3} / \mathrm{s}$ was well in excess of a 100-year flood. The water-surface elevation at the downstream end of the indirect-measurement reach $(16,500 \mathrm{ft}$ upstream from the mouth) was $812 \mathrm{ft}$ above sea level, corresponding to a stream depth of $16 \mathrm{ft}$.

The flood profile shown in figure 8 generally paralleled the streambed profile, although, in some cases, the water surface was unaffected by some of the irregularities in the stream channel. For example, the series of 3 - to 5 -foot-high waterfalls in the reach 16,000 to 18,500 ft upstream from the mouth does not affect the flood profile. At the 14-foot-high waterfall and pool 10,000 ft upstream from the mouth, however, the profile is affected. Stream depths in the reach averaged $16 \mathrm{ft}$ and ranged from $10 \mathrm{ft}$ in steep sections to $22 \mathrm{ft}$ at the mouth.

\section{FLOODING IN BELMONT, JEFFERSON, AND HARRISON COUNTIES}

Two types of streamflow gages were used to analyze the areal distribution of the flood of June 14-15, 1990 (fig.9). The progression of the flood, its peak, and its recession were recorded at three continuous-record streamflow-gaging stations: Short Creek near Dillonvale (03111500), Wheeling Creek below Blaine (0311548), and Captina Creek at Armstrongs Mills (03114000). Peak discharges north and west of the continuousrecord stations were determined from three partial-record creststage gages: Clear Fork near Jewett (03127950), Branson Run at Georgetown (0311450), and South Fork Short Creek at Georgetown (03111455). These partial-record crest-stage gages had been discontinued in 1987, but high-water marks at these gages were obtained and used in this study.

No streamflow gages were ever established on Pipe and Wegee Creeks. Discharge for the miscellaneous sites on Pipe and Wegee Creeks were determined from indirect measurements made after the 


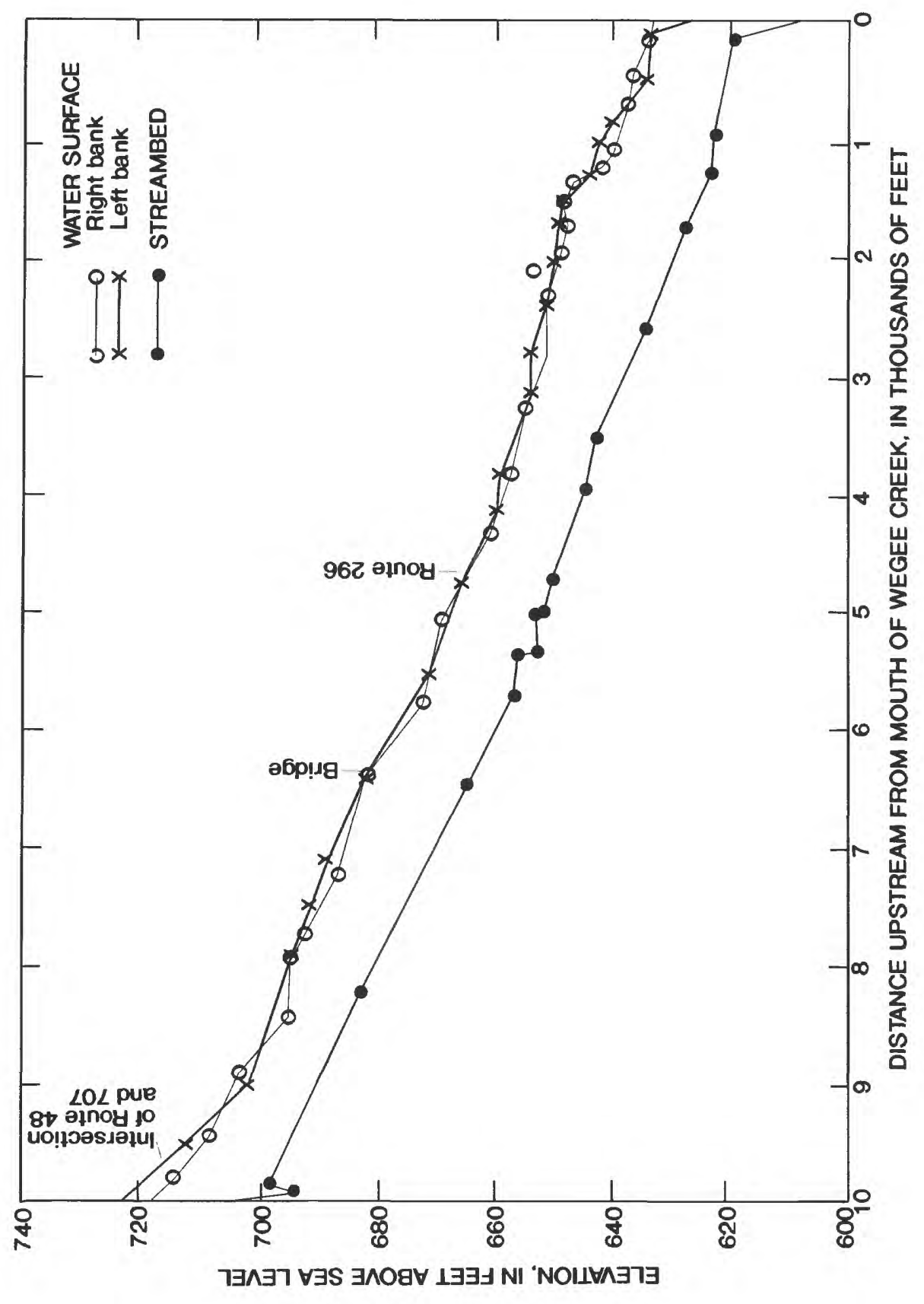

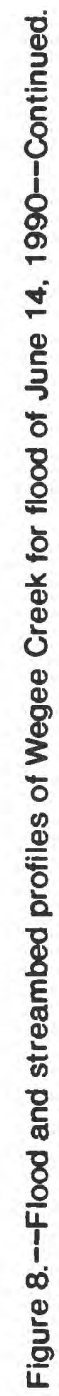




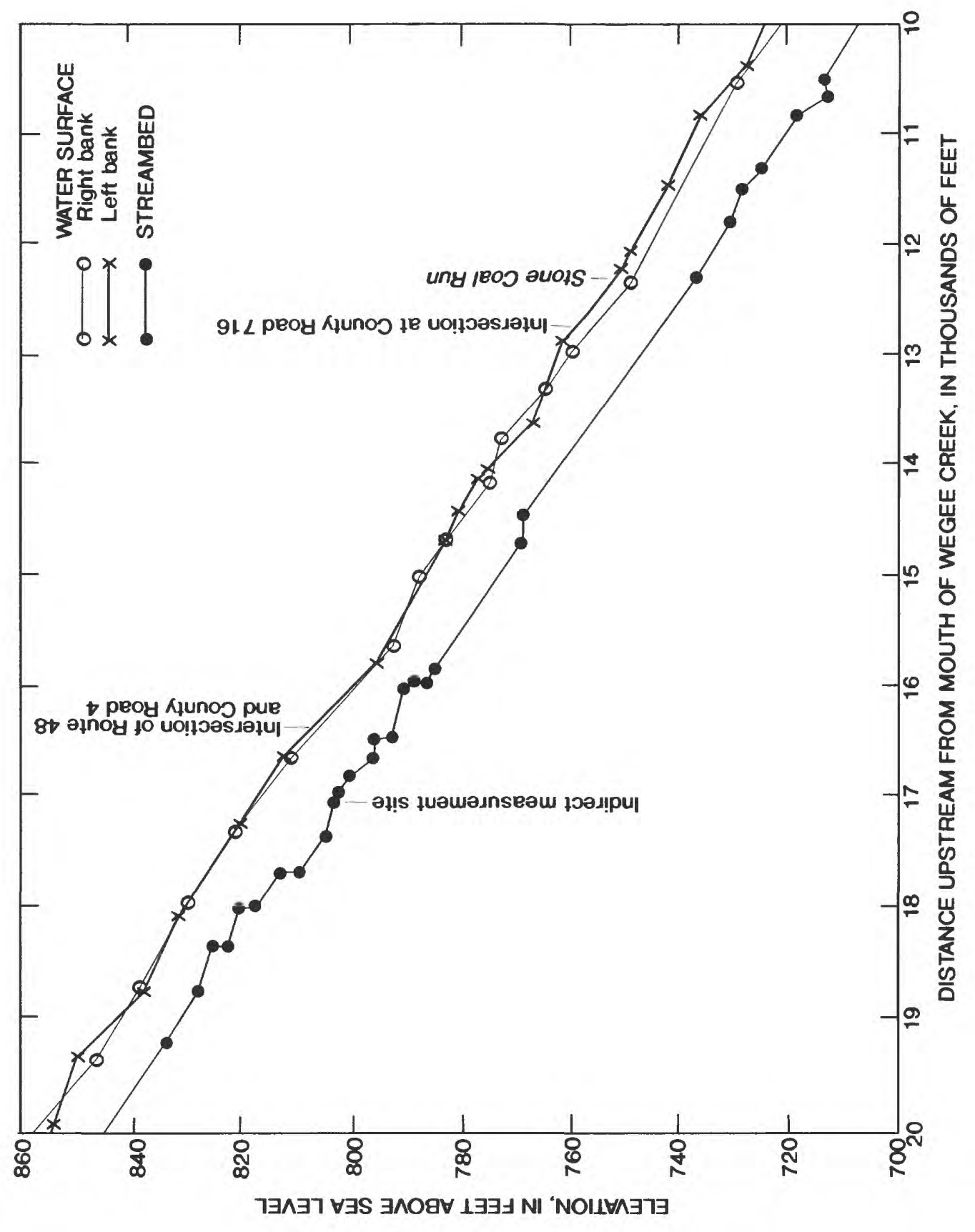

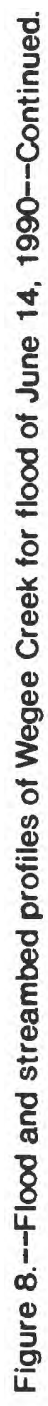




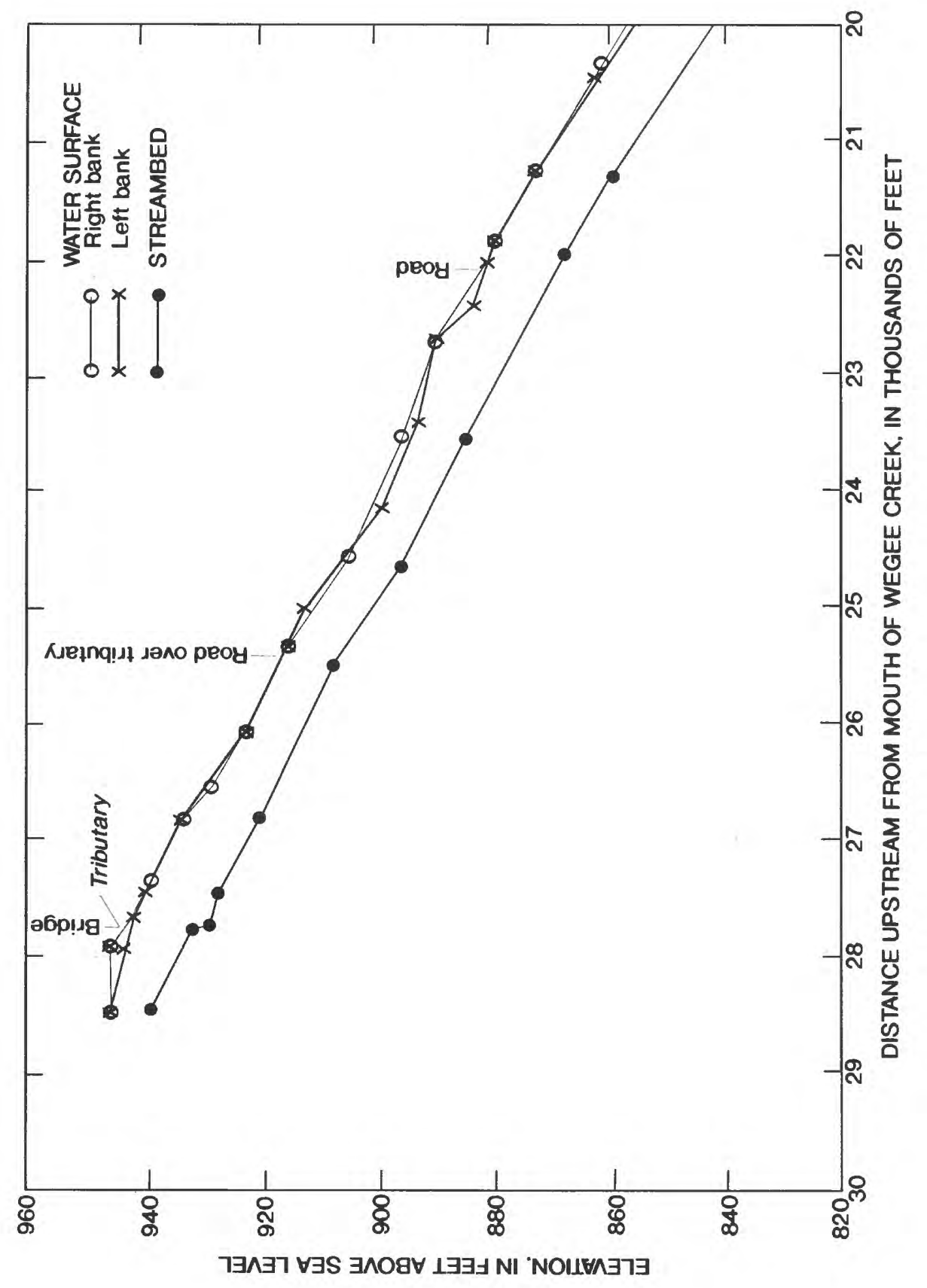

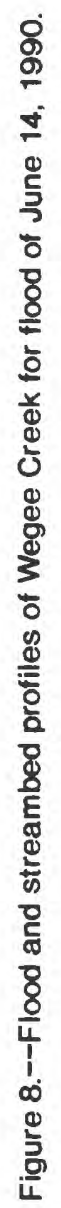




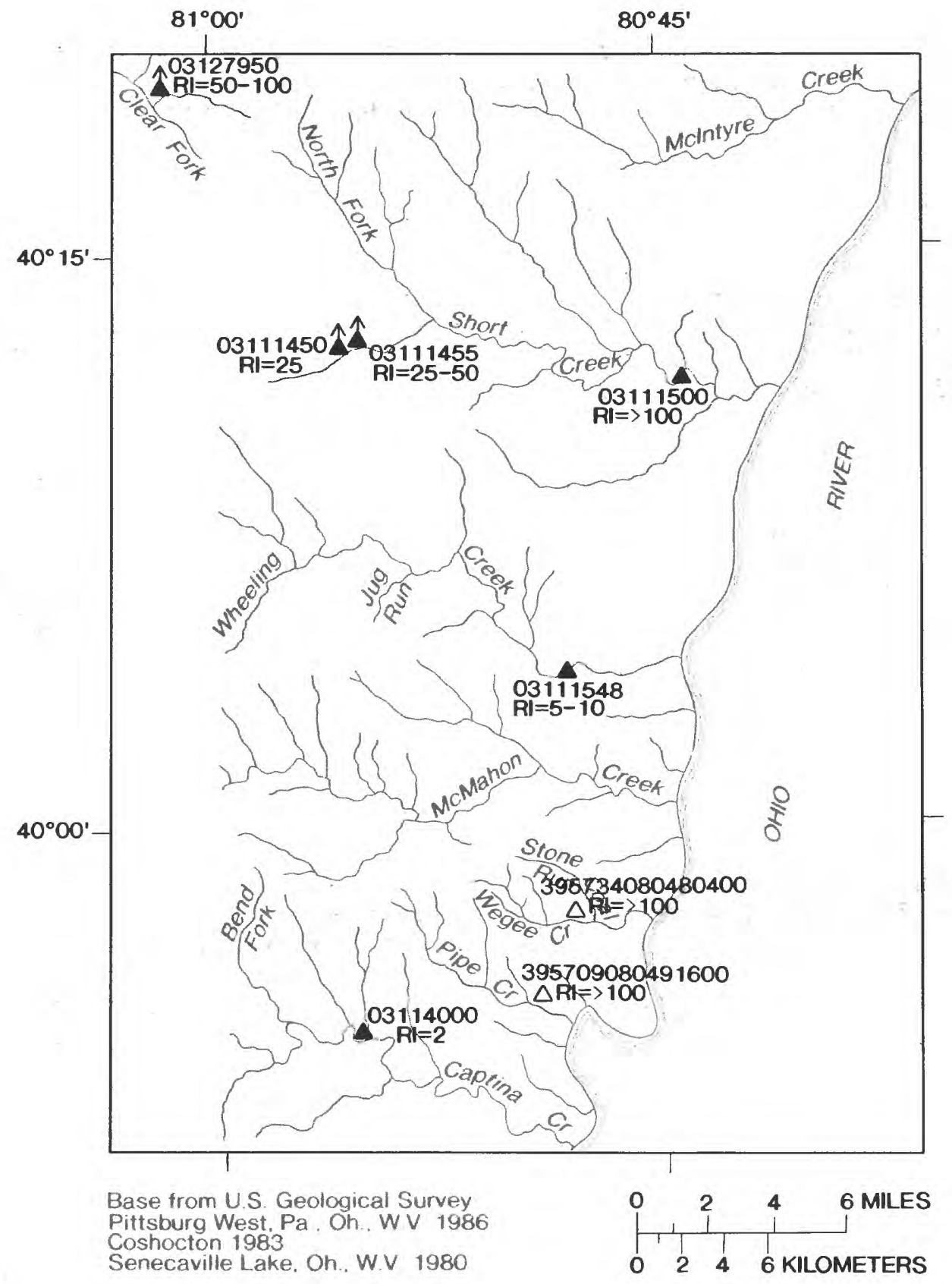

Study Area

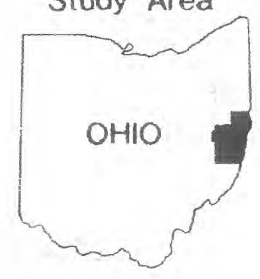

\section{EXPLANATION}

STREAMFLOW-MEASUREMENT STATIONS AND SITES--Eight- or fifteen-digit number adjacent to symbol is the station or site number Continuous-record station

个 Crest-stage station

$\triangle \quad$ Indirect-measurement site

RI=2 RECURRENCE INTERVAL, IN YEARS-->, greater than: see Table 1

Figure 9.--Continuous-record gaging stations, partial-record crest-stage gages, and miscellaneous sites with area recurrence intervals of the June 14, 1990, flood. 
flood on June 14-15. Information from the continuous-record stations, partial-record crest-stage gages, and indirect measurements are summarized in figure 9 and in table 1.

\section{Areal Distribution of Flooding}

Flood severity varied considerably throughout the threecounty area. Recurrence intervals of peak discharges at the stations listed in table 1 range from 2 years to greater than 100 years. The maximum discharge for the period of record was recorded during this flood at the Short Creek streamflow-gaging station. Short Creek and Captina Creek are $22 \mathrm{mi}$ apart; however, the recurrence interval of the peak discharge at the Captina Creek station was 2 years, whereas the recurrence interval of the peak discharge at the short Creek station was greater than 100 years. Similarly, the peak discharge at the miscellaneous site on $\mathrm{Pipe}$ Creek was $15,000 \mathrm{ft} / \mathrm{s}$ with a recurrence interval greater than 100 years, whereas the Captina Creek peak discharge was $6,080 \mathrm{ft}^{3} / \mathrm{s}$ with a recurrence interval of 2 years; these two sites are only $5 \mathrm{mi}$ apart.

\section{Historical Perspective}

Flash flooding on streams in Belmont, Jefferson, and Harrison Counties is not uncommon. Numerous floods are noted throughout the historical records of this area; accounts of many of these floods have been compiled in the "Supplemental Information" section at the back of this report. Some of those past floods could have been as hydrologically significant as the flood of June 14-15, 1990, but may have caused much less damage. According to Margaret Kirkland, a resident of Belmont County and a local historian, "Since World War II, more people live in these creek valleys, especially with the popularity of mobile homes as a way of living. Much of the land in the creek valleys used to be farmed but is now used for home sites."

Historical accounts indicate that as many as six major floods may have occurred in the three-county area since the early $1800^{\prime} \mathrm{s}$. Most of the small streams in the area have never been part of a systematic streamflow-data-collection network, however, so there is no scientific basis for corroborating historical accounts of flooding. Paleoflood investigations--studies of prehistoric movement of water and sediment in channels--have been shown to produce reasonable estimates of flood magnitude and frequency in areas where systematic streamflow data are lacking (Hupp, 1987). Paleoflood investigations may ultimately be necessary if a scientific approach is taken for determining regional probabilities of major flooding in narrow stream valleys of Belmont, Jefferson, and Harrison Counties. 


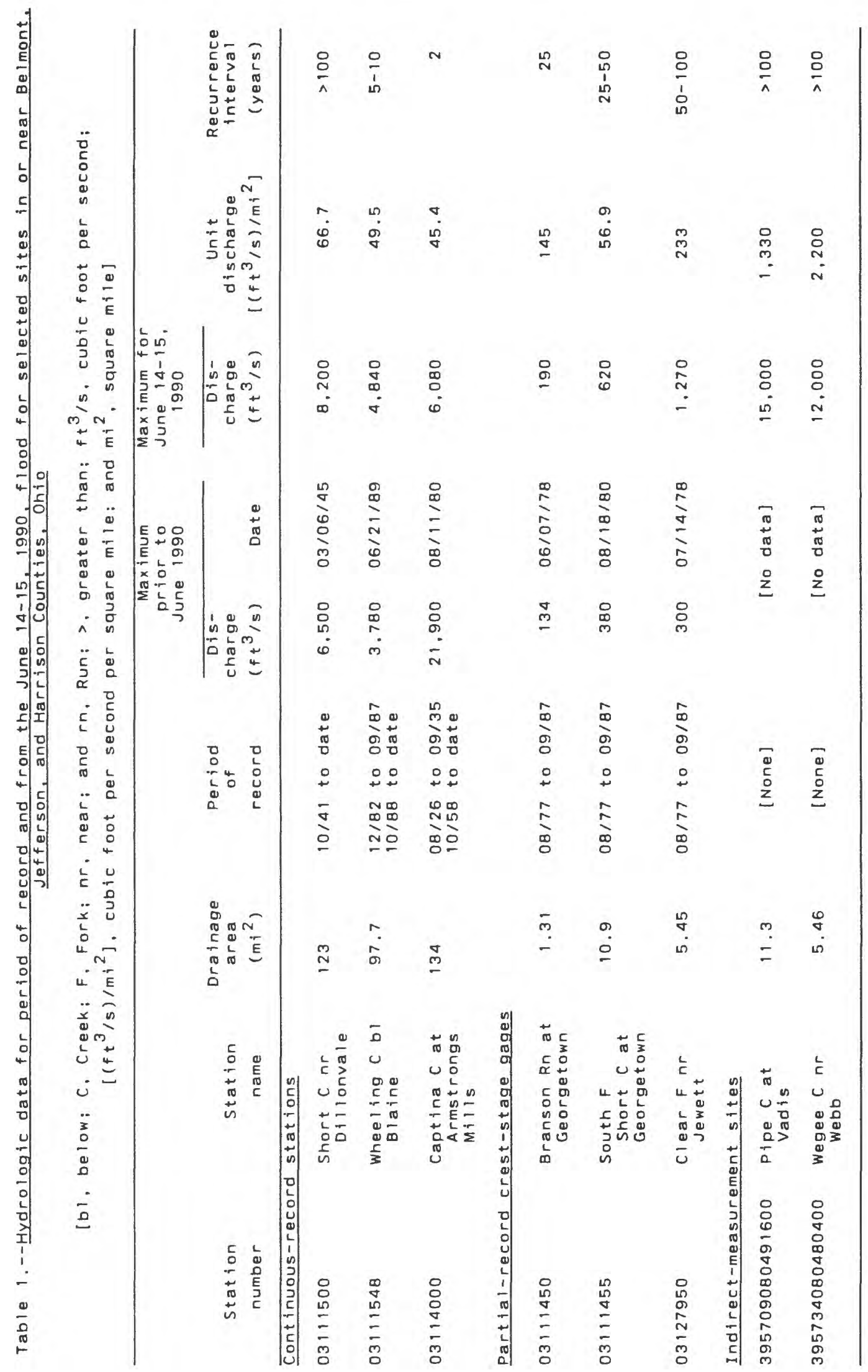




\section{SUMMARY AND CONCLUSIONS}

Storms during the evening of June 14, 1990, caused extensive flooding in Ohio, with disastrous results in the Pipe and Wegee creek basins. An extremely wet spring reduced the soil's capacity to absorb any significant additional precipitation. The strong line of thunderstorms that moved across the state on June 14 culminated in an unusually severe weather pattern, which produced roughly 3 to 5 inches of rain over the three-county area during the early evening hours when most people were at home. The steep narrow valleys of the Pipe and Wegee Creek basins concentrated the flow and produced flash flooding. At least 24 people lost their lives, and millions of dollars in damage was done.

An indirect measurement made 4,600 ft upstream from the mouth of $P$ ipe Creek indicated a peak discharge of $15,900 \mathrm{ft}^{3} / \mathrm{s}$ and a corresponding unit discharge of $1,330(\mathrm{ft} / \mathrm{s}) / \mathrm{mi}^{2}$. An indirect measurement made $17,000 \mathrm{ft}$ upstream from the mouth of Wegee Creek indicated a peak discharge of $12,000 \mathrm{ft}^{3} / \mathrm{s}$ and a corresponding unit discharge of $2,200 \mathrm{ft}^{3} / \mathrm{s}$. The recurrence interval for each of these peak discharges is greater than 100 years.

The average depth of water in Pipe Creek was $14 \mathrm{ft}$ for the entire surveyed reach and ranged from $7 \mathrm{ft}$ near the headwaters to $17 \mathrm{ft}$ near the mouth. The average depth of water in Wegee Creek for the entire surveyed reach was $16 \mathrm{ft}$ and ranged from $10 \mathrm{ft}$ in steep sections to $22 \mathrm{ft}$ at the mouth.

Flood severity varied considerably throughout the threecounty area. Recurrence intervals of peak discharges at the stations listed in table 1 range from 2 years to greater than 100 years. The maximum discharge for the period of record was recorded during this flood at the short creek streamflow-gaging station. Short Creek and Captina Creek are $22 \mathrm{mi}$ apart; however, the recurrence interval of the peak discharge at the captina Creek station was 2 years, whereas the recurrence interval of the peak discharge at the Short Creek station was greater than 100 years. Similarly, the peak gischarge at the miscellaneous site on Pipe Creek was $15,000 \mathrm{ft} / \mathrm{s}$ with a recurrence interval greater than 100 years, whereas the Captina Creek peak discharge was $6,080 \mathrm{ft}^{3} / \mathrm{s}$ with a recurrence interval of 2 years; these two sites are only $5 \mathrm{mi}$ apart.

Results of statistical analyses contrast with reports of severity and frequency of flooding in historical accounts from the three-county area. For example, the peak discharge on Wegee Creek was more than six times that of the 100-year flood estimated by use of the regional equation; yet, historical accounts indicate that floods of similar magnitude may have occurred at least two other times in the last 100 years. paleoflood investigations may be necessary to resolve the apparent discrepancies. 


\section{SELECTED REFERENCES}

Beaulieu, L.S., 1990, Town center little touched by waters: Columbus (Ohio) Dispatch, June 17, 1990, p. ID.

--- 1990, Raging water brings death, destruction: Columbus (Ohio) Dispatch, June 16, 1990, p. 1A.

Bellaire Daily Leader, 1919, Nine lives and property loss estimated at million is toll of flood in the valley of Wegee Creek: July 21, 1919, p. 1 .

Caldwell, J.A., 1880, History of Belmont and Jefferson Counties: Wheeling, W. Va., Historical Publication company (Reprinted in Evansville, Ind., by Unigraphic, 1976), 611 p.

Cashell, D.H., 1990, Monthly water inventory report for Ohio: Ohio Department of Natural Resources, May, 4 p.

Dalrymple, Tate, and Benson, M.A., 1967, Measurement of peak discharge by the slope-area method: U.S. Geological Survey Techniques of Water-Resources Investigations, book 3 , chap. A2, $12 \mathrm{p}$.

Hupp, C.R., 1987, Botanical evidence of floods and paleohistory, in Singh, V.P., ed., Regional flood frequency analysis: Dordrecht, Holland, D. Reidel Publishing Company, p. 355369.

Jacobs, David, 1990, 9-year-old girl survives watery nightmare: Columbus (Ohio) Dispatch, June 16, 1990, p. IA.

Jarrett, R.D., and Costa, J.E., 1986, Hydrology, geomorphology, and dam break modeling of the July 15, 1982 Lawn Lake Dam and Cascade Lake Dam failures, Larimer County, Colorado: U.S. Geological Survey Professional Paper 1369, 78 p.

Koltun, G.F., and Roberts, J.W., 1990, Techniques for estimating flood-peak discharges of rural, unregulated streams in Ohio: U.S. Geological Survey Water-Resources Investigations Report 89-4126, $68 \mathrm{p}$.

Mckelvey, A.T., 1903, Centennial history of Belmont County: Chicago, Ill., Biographical Publishing Co. (Reprinted in Knightown, Ind., by Bookmark, 1977), 833 p.

National Weather Service, 1990, Drought severity index by division: Weekly Weather and Crop Bulletin, June 9, 1990: p. 5 .

---- 1991, Natural disaster survey report, Shadyside, Ohio-flash floods, June 14, 1990: 48 p. 
Shindel, H.L., and others, 1990, Water resources data, Ohio, water year 1989: U.S. Geological Survey Water-Data Report $\mathrm{OH}-89-1,312 \mathrm{p}$.

Switzer, John, 1990, County declared disaster area: Columbus (Ohio) Dispatch, June 16, 1990, p. $12 \mathrm{~A}$.

Trieste, D.J., and Jarrett, R.D., 1987, Roughness coefficients of large floods, in James, L.G., and English, M.J., eds.., Irrigation and Drainage Division Specialty Conference-Irrigation systems for the 21 st century, Portland, Or., 1987, Proceedings: New York, American Society of Civil Engineers, p. 32-40. 


\section{SUPPLEMENTAL INFORMATION}

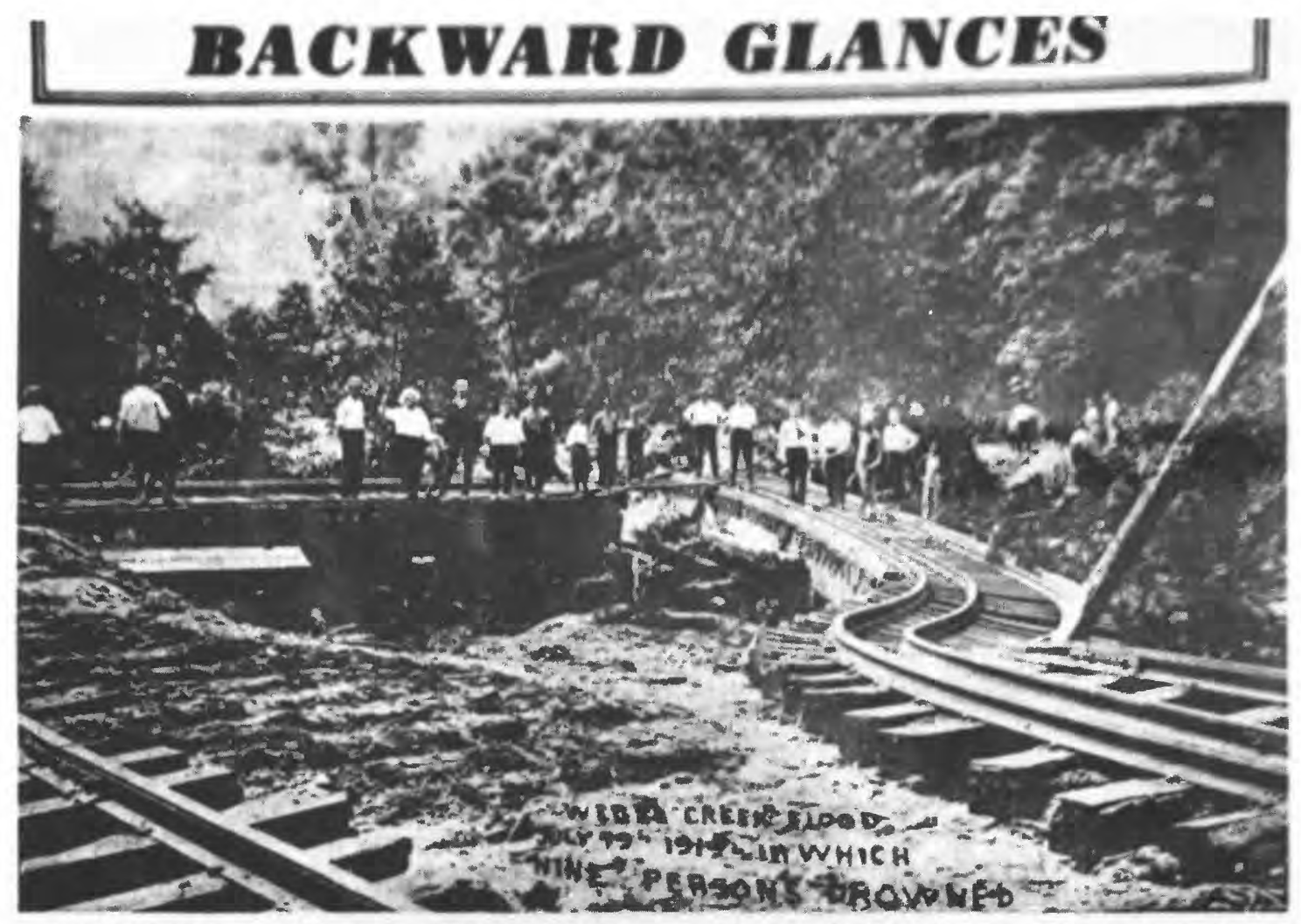

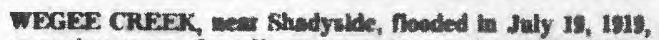
sweeplas acress e edjecent cemetery and carrytag boes dowe strean. Twe ralli in that area were thrown cato the

cemetery ground and a namber of people drowned wear what th new the Shadyside Lioas Club.

Photograph of photocopy from Martins Ferry Times-Leader Newspaper. courtesy of Margaret Kirkland. 
Much of this section was developed from information supplied by Margaret Kirkland (written commun., 1990), a retired educator currently working on a publication of Belmont County's history. Her work is based on newspaper files, Caldwell's "History of Belmont and Jefferson Counties" (1880), McKelvey's "Centennial History of Belmont County" (1903), and interviews of a number of county residents.

The following quotations are excerpts from various historical and eyewitness accounts of past flooding in the three-county area.

\title{
Flood of 1818--Hardesty Flood
}

The flood known as the Hardesty Flood occurred in about 1818 on McMahon's Creek. It was styled thus owing to the fact that Mr. John Hardesty and family-wife and five children--were drowned in it. He lived near the banks of this stream and the waters rose to such a height that his house was inundated and carried off on the resistless bosom of the angry turbid waters. After the waters had abated he and his wife's body were recovered a short distance from where the house stood. The remains of two of his children were regained a considerable distance below, in the stream. The other children were never found. Major Thompson, of St. Clairsville, says, that several days after the flood, he passed down that way on horseback, and saw straw and litter lodged on the branches of trees along the creek, so high above him that he was unable to reach with his whip from his horse. The ravages of the flood were immense with great loss of property. It is said that the waters came down with such power as to cause the drift, bourne on its bosom, to be swept across on the opposite banks of the Ohio River.

\author{
(Caldwell, 1880)
}


On Sabbath evening, August 12, 1866, the storm swept over Wheeling Creek valley from Flushing on the west to the Ohio River and beyond. For hours the sky was illuminated by continuous streams of lightning. The thunder pealed continuously and the rain fell in torrents. In a few hours Wheeling Creek had overflown its banks and, at a point between Barton and the foot of the "big hill" the log house of Kellis Robinson was washed away, and father, mother, and five children were drowned. At Oglebay's Mill, the creek broke over the narrow channel that carried water into the dam, and washed nearly an acre of land away, the course of the stream was completely changed.

$$
\star \star \star *
$$

The loss of personal property was terrible--some farmers lost their entire crop, fields of corn ranging from 10 to 30 acres were completely washed away and several small bridges between the foot of the "big hill" and $\mathrm{Bridgeport}$ were destroyed. In addition to the seven drowned, two were killed by lightning.

(McKelvey, 1903)

Flood of 1881

In the month of May, 1881, a rain storm of a character similar to that narrated above broke over St. Clairsville and the county northward. The little stream running north of the town and known as "Jug Run" became a raging canal of water that swept its narrow channel from bank to bank, carrying off everything that was moveable. Along the line of "Jug Run" fences and bridges were washed away, and the road was literally destroyed.

The St. Clairsville \& Northern Railroad had just been completed at an expense of about $\$ 30,000$ and in a brief hour was undone, and it became necessary to build the road anew. Many families were driven out of their homes by the water and numbers barely escaped with their lives.

$$
\text { (McKelvey, 1903) }
$$


[The Great Flood of 1884] nearly destroyed

Businessburg. The waters of Pipe Creek rose to a height of 15 feet, and the town was practically submerged. Many houses were carried away and the loss was very heavy.

$$
\text { (McKelvey, 1903) }
$$

\section{Flood of 1888}

The year following the great cyclone of 1887 , previously mentioned, the St. Clairsville branch of the Baltimore and Ohio Railroad, with the exception of a mile or more near st. Clairsville, was literally washed away by an unprecedented flood on Little McMechen's (McMahon's) creek. The rain storm was a veritable cloudburst, washing away houses, bridges, and fences. A great wall of water surrounded an approaching train with a passenger coach well filled with passengers. The train was compelled to stop and although the water nearly engulfed it, the engine and car withstood the shock and the passengers were saved. Nearly everyone living on the borders of the creek suffered and the railroad was so badly damaged it was necessary to rebuild it. The loss was estimated at $\$ 200,000$.

$$
\text { (Mckelvey, 1903) }
$$

Flood of 1896

\section{"WEGEE CREEK VALLEY SWEPT BEFORE"}

It was almost 23 years to a day from the awful catastrophy of Saturday night, that Wegee Creek first overflowed its banks to a depth of 30 feet and swept everything before it. That the property damage and loss of life in the first flood was not greater than that saturday night was due only to the fact that the creek valley was not nearly so thickly populated as it is at the present time.

Three were drowned in the flood of 23 years ago, consisting of a man, his wife, and one child. They resided in the valley of the creek and the water came up so rapidly that they were caught unaware. Their bodies were never recovered.

Crops in the creek valley at that time were ruined and the damage totalled thousands of dollars.

(Bellaire Daily Leader, July, 1919, [Fig. 10]) 


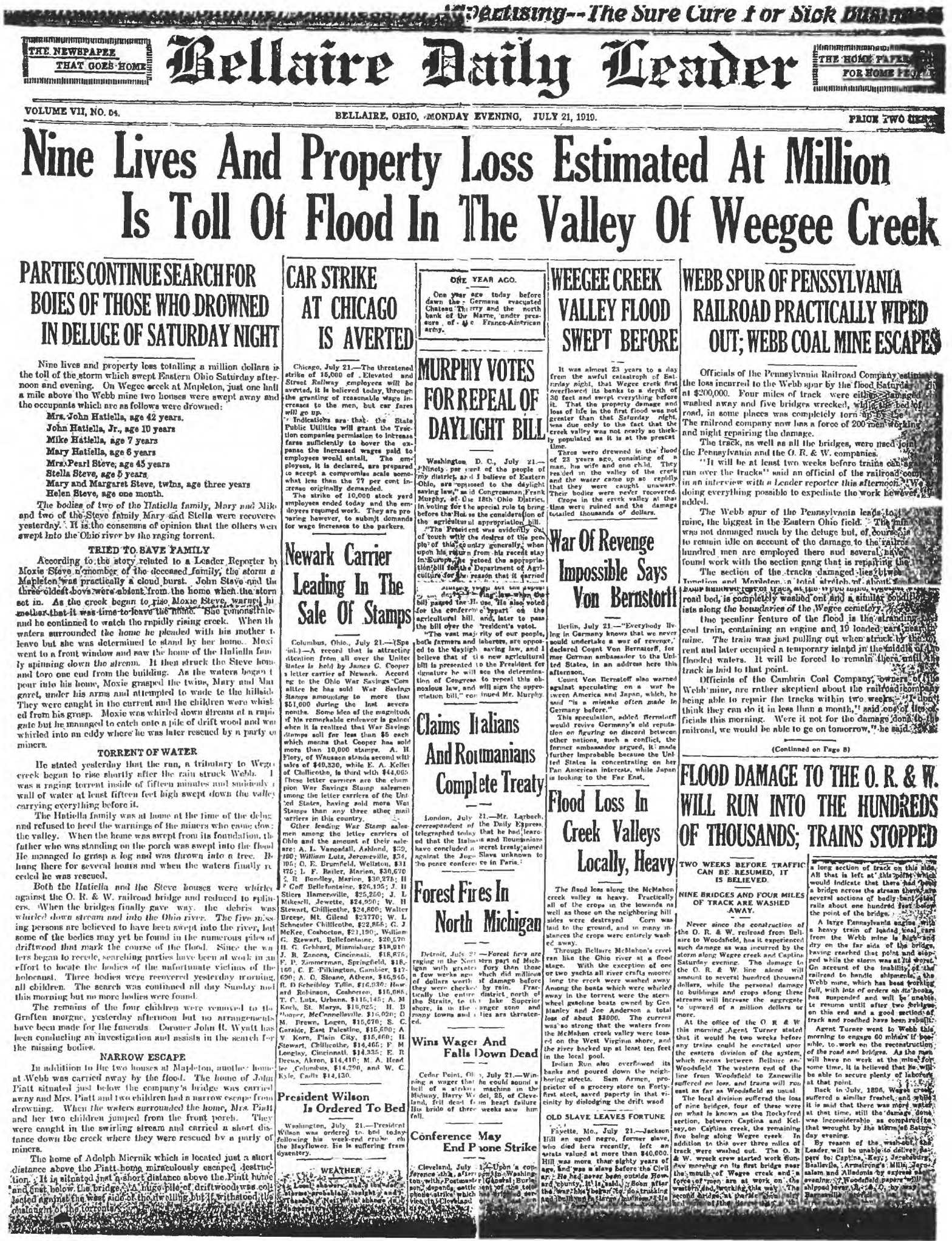

Figure 10.--Photoreporduction of front page of Bellaire Daily Leader for Monday, July 21, 1919. 
Flood of 1919

"NINE LIVES AND PROPERTY LOSS ESTIMATED AT MILLION IS TOLL OF FLOOD IN THE VALLEY OF WEGEE CREEK"

"PARTIES CONTINUE SEARCH FOR BODIES OF THOSE WHO DROWNED IN DELUGE OF SATURDAY NIGHT"

Nine lives and property loss totalling a million dollars is the toll of the storm which swept Eastern ohio Saturday afternoon and evening. On Wegee Creek at Mapleton, just one half mile above the Webb mine two houses were swept away and the inhabitants * * * were drowned.

According to a story related to a Leader Reporter by Moxie Steve, a member of the deceased family, the storm at Mapleton was practically a cloud burst * * $\star \mathrm{He}$ stated yesterday that the run, a tributary to Wegee Creek, began to rise shortly after the rain struck Webb. It was a raging torrent inside of fifteen minutes and suddenly a wall of water at least fifteen feet high swept down the valley carrying everything before it. * * *

"FLOOD DAMAGE TO THE OR\&W WILL RUN INTO THE HUNDREDS OF THOUSANDS; TRAINS STOPPED"

Two weeks before traffic can be resumed it is believed. Nine bridges and four miles of track are washed away. Never since the construction of the OR\&W railroad from Bellaire to Woodsfield, has it experienced such damage as was incurred by the storm along Wegee Creek and Captina Saturday evening. The damage to the OR\&W line alone will amount to several hundred thousand dollars, while the personal damage to buildings and crops along these streams will increase the aggregate damage to upward of a million dollars or more. * * *

"WEBB SPUR OF PENNSYLVANIA RAILROAD PRACTICALLY WIPED OUT; WEBB COAL MINE ESCAPES." * * *

"FLOOD LOSS IN CREEK VALLEYS LOCALLY HEAVY"

The flood loss along the McMahon Creek valley is heavy. Practically all of the crops in the lowlands as well as those on the neighboring hillsides were destroyed. Corn was laid to the ground, and in many instances the crops were entirely washed away. Through Bellaire McMahon's Creek ran like the Ohio River at a flood stage.

(Bellaire Daily Leader, 1919) 
Miss Kirkland mentions another flood of the 1930's:

When I was a child, I remember a flash flood which occurred on Wheeling Creek in Blaine and Barton near Bridgeport, Ohio. Flood waters covered old Route 40 and surrounding land in that area. We were in St. Clairsville visiting my aunt and uncle when it happened. We all went down to see the flood. 